\title{
APPROACHING EMOTIONAL DEFICITS THROUGH THE LENS OF EPIGENETICS. THE SENSORY SUBLIMATION OF TRAUMA IN ANNA WIŚNIEWSKA-GRABARCZYK'S PORZECZKOWY JOSEF
}

\section{KEY WORDS}

Anna Wiśniewska-Grabarczyk; literature and memory; postmemory; epigenetics; Shoah

Porzeczkowy Josef (Currant Josef) is Anna Wiśniewska-Grabarczyk's prose debut. In 2019, it was nominated for the Witold Gombrowicz Literary Award. This double-layered novel can be read, on the one hand, as a record (in the form of a first-person narrative) of a granddaughter's memories of the time that she spent with her grandmother in a house with a garden, previously owned by a German family, and, on the other, as a record of modes of coping with the difficult concentration camp experiences which the granddaughter has in a sense "inherited" from her grandmother and which remain suppressed in the subconscious. In the concealed memories that have never been voiced, love is mixed with hatred and the victim's attachment to the perpetrator - with shame. Stemming from the painful experiences of the past, the emotional deficits of the two protagonists are sublimated through the richness of sensory impressions described in the novel, in which smell, taste and touch play a major role in coping with trauma.

Although a work of literature cannot and should not be treated as an example illustrating a psycho-biological theory, the category of trauma is deeply rooted

Marzena Woźniak-Łabieniec - dr hab. prof. UŁ, Department of the 20th- and 21st-century Polish Literature, Institute of Polish Studies and Logopedics, Faculty of Philology, University of Łódź, ul. Pomorska 171/173, 90-236 Łódź; e-mail: marzena.wozniak@uni.lodz.pl; https://orcid. org/0000-0003-3280-1411. 
in the narrative of Porzeczkowy Josef. "[E]xtensively used in several domains of the humanities because of its usefulness in diagnosing the condition of a (post) modern subject struggling with the heavy [...] burden of the extreme experiences of the 20 $0^{\text {th }}$-century history" (Bilczewski 2013: 40; see also Bojarska 2013: 247 et seq.), the concept and theory of trauma as well epigenetics are thus useful analytical tools that help examine the novel.

\section{Epigenetics and Postmemory}

Epigenetics is the study of hereditary changes in the expression of genes which are not related to the changes in DNA chains. According to Alon Chen, the director at the Max Planck Institute of Psychiatry, who has for many years studied non-genetic heredity,

Just as DNA is transmitted onto new generations, a similar thing happens to the so-called "epigenetic record". Currently, we can identify such qualities up to three generations back. If, for example, one considers the third generation of Holocaust survivors or the grandchildren of the soldiers who fought in the Second World War, there are still traces of epigenetic trauma in them. As a result, those people are more timid and susceptible to stress-related diseases (Chen 2019).

Therefore, according to epigeneticists, apart from genes what we also inherit from our ancestors in a non-genetic manner are: the memory of fear, and mental or somatic disorders. Dramatic experiences produce stress and trauma which have an impact on new generations even if they have not experienced the causes of those experiences themselves.

In the humanities, epigenetic heredity is somewhat reflected in the term 'postmemory', which was first formulated by the American scholar Marianne Hirsch. She thus defines this phenomenon:

Postmemory is distinguished from memory by generational distance and from history by deep personal connection. Postmemory is a powerful and very particular form of memory precisely because its connection to its object or source is mediated not trough recollection but through an imaginative investment and creation. This is not to say that memory itself is unmediated but that it is more directly connected to the past. Postmemory characterizes the experience of those who grow up dominated by narratives that preceded their birth, whose own belated stories are evacuated by the stories of the previous generation shaped by traumatic events that can be neither understood nor recreated (Hirsch 2012: 22).

In Hirsch's approach, postmemory applies mainly to the generation of the victims' children who grew up, having inherited their parents' trauma, in an 
atmosphere of tragic memories (mainly associated with the Holocaust), and it may also be experienced by larger communities afflicted by a collective disaster.

However, according to epigeneticists, the impact of traumatic experiences on one's epigenome can reach much further - it does not only result from the accounts passed down from generation to generation or growing up in the atmosphere of trauma. People who experience trauma-based anxiety may not be aware of the experiences of their ancestors. It is often the case that the victims of trauma are not able to share their experiences with anyone and they decide to remain silent for decades (that was the case with the original protagonist of Porzeczkowy Josef). In terms of statistics, the reach of intergenerational trauma is long (up to three generations) - i.e. those who experience it may be the grandchildren of the victims. As Jadwiga Jośko-Ochojska argues,

Trauma in a family is often a taboo when ethical and moral norms have been violated and when family members are ashamed of what happened (rape, sexual harassment, domestic violence, $[\ldots]$, etc.). Another taboo is a situation in which people who experienced traumatic events suffer from PTSD. They do not wish to return to their terrible memories, people, or places which they directly associate with those events. Emotional memory which one stores in one's mind for many years and, apparently, transfers onto new generations is very resilient. The difference is that the people who belong to new generations are not able to explain to themselves their anxiety and their incomprehensible behaviour because they do not know their family's history (Jośko-Ochojska 2018).

For several years now, the epigenetic perspective has been gaining in popularity in literary research. In Polish literary studies, Anna Artwińska used this theory in her analysis of Anna Janko's Mata Zagtada (Artwińska 2016). It has also been applied in the field of comparative cultural studies by Tomasz Bilczewski (Bilczewski 2013). Recapitulating contemporary research on postmemory, he accentuates the nature of epigenetic transmission, contextualizing the phenomenon in medical and psychiatric perspectives. Referring to Polish literature, he thus argues that

Studies into the structure of the genome and the operation of epigenetic mechanisms may in the future clarify many doubts regarding the process of intergenerational transfer - of more than just trauma - shedding new light on the interpretation of the problems raised in the literary works of [Eva] Hoffman and in the works of such authors as: Ewa Kuryluk, Piotr Paziński, Andrzej Bart, Anda Rottenberg, Magdalena Tulli, Bożena Keff, Piotr Szewc, Marek Bieńczyk, Mieczysław Abramowicz, Agata Tuszyńska, and Igor Ostachowicz (Bilczewski 2013: 60). 


\section{Approaching Porzeczkowy Josef from an Autobiographical Perspective}

Anna Wiśniewska-Grabarczyk's novel refers to the history of her family. It alludes to the war-time and occupation fortunes of Józefa Wiśniewska, her grandma, her father's mother (the novel presents the author's grandmother's actual personal details), ${ }^{1}$ who in 1944-1945 experienced dramatic events in the Nazi Bergen-Belsen concentration camp. One internee recollected that in Bergen-Belsen "the conditions were 1000 times worse than in Ravensbrück", that the camp was located "in a boggy and muddy area", and that internees slept in stables on the ground. Terrible sanitary conditions caused the spread of "typhoid fever, epidemic typhus, dysentery, lice, and hunger" (Czyż 2013: 80-81). The name in the title of the novel is the name of Hauptsturmführer Josef Kramer, the camp's commandant at that time, who was widely known for his cruelty. According to Nikolaus Wachsmann,

he had brought more suffering to the camp after his arrival in early December 1944. And when the full tragedy unfolded, Kramer and his men mostly watched from the sidelines, not least to protect themselves from disease. During March 1945, the sight of SS officials became rare inside the Bergen-Belsen compounds (Wachsmann 2015: 568).

During that time, the camp was referred to as the "dying room".

The lack of water was severe. Prisoners drank dirty water from basins in which corpses were floating. Cannibalism was spreading as a result of pervasive hunger. Once the camp was liberated, soldiers kept finding corpses with severed body parts. As we learn from The Holocaust Encyclopedia,

Bergen-Belsen was hell on earth. [...] By early 1945, prisoners would sometimes go without food for days; fresh water was also in short supply. Sanitation was incredibly inadequate, with few latrines and water faucets for the tens of thousands of prisoners interned in Bergen-Belsen at this time. Overcrowding, poor sanitary conditions, and the lack of adequate food, water, and shelter led to an outbreak of diseases such as typhus, tuberculosis, typhoid fever, and dysentery, causing an ever-increasing number of deaths. In the first few months of 1945, tens of thousands of prisoners died (Bergen-Belsen 2020).

Based on the above-mentioned accounts, one can conclude that hunger was a particularly painful experience for the prisoners interned at Bergen-Belsen, a fact which is significant in the context of the novel under discussion. In Porzeczkowy Josef, the deficit associated with the lack of food, i.e. a bodily

1 The same concerns the names of the other members of her family included in the novel (Anna, Paweł). 
deficit, reflects emotional deficits, those that have been ousted or suppressed in one's subconscious.

The story unfolds at the turn of the 1990s in Trzcianka, in a formerly German house of Józefa Wiśniewska, who is often visited by her granddaughter Ania. This is where the biographical accuracy of the novel ends, with the exception of a few minor events and figures (the father, mum, Pawel, friend), whose actual fortunes the novel does not reproduce. That is because it is not a typical memoir. Time follows its own rules, and events are organised in accordance with the natural time (seasonal changes) rather than the human time measurement. Moreover, time is in a state of entanglement. Death, youth, childhood, and maturity intersect with each other, without any specific chronology. This effect is achieved both by retrospections and leaps into the future, foreshadowing things to come. It is a record of a spiritual "journey" through space and time - a journey through an often painful family history. Such a mode of representing time also supports the argument that the course of life's events depends on coincidences, often related to people whom we do not know but who enter into our lives to play significant parts in them and who make us major actors in their own stories.

\section{Grandmother and Granddaughter. Inherited Trauma}

The novel's erudition and intertextual references (e.g. to Bruno Schulz's works), as well as the use of magical realism and oneiric symbolism become the basis for the multi-layered coding of meanings. This mode of creating the fictional world enabled the author to introduce the eponymous character into the space of Józefa W.'s house. He is presented as a guest or, actually, a tenant. Josef "has become an integral and necessary part of her [Józefa’s] life" (Wiśniewska-Grabarczyk 2018: 20). ${ }^{2}$ He keeps appearing and vanishing.

The representation of the space plays a major role in accentuating the presence of the Nazi perpetrator in his victim's post-WWII life. The distorted landscape of Trzcianka (similar to Schulz's Drohobycz) is essentially oneiric and encourages interpretations through the prism of Jung's symbolic categories. Jung saw dreams as reflection of the subconscious. Therefore, Józefa W.'s house, with its attic and basement, could be viewed as the reflection of her internal life. Josef is initially hidden, mainly in the attic. Yet sometimes, against the will of other residents, he descends into the basement. The attic in a dream symbolises past experiences and old recollections. It also indicates long forgotten or suppressed hardships, experiences and emotions stored in the subconscious. Gradually, as the years go by, the victim-perpetrator relationship turns into a care relationship.

\footnotetext{
2 All quotations from the novel have been translated by Anna Wiśniewska-Grabarczyk.
} 
Josef gradually starts leaving the attic and, with Józefa W.'s consent, begins to use the kitchen and the living quarters more and more often; even more so, he takes the place of her dead husband when he starts sleeping in his bed, sitting in his armchair, attending meals, and wearing his clothes and shoes which he gets from Józefa (Wiśniewska-Grabarczyk 2018: 50-51, 56, 75, 82, 94, 131). Józefa, then, undergoes a process which could be referred to as taming trauma, coming to terms with her past, and in some way accepting it (the accidental similarity of their names, Józefa and Josef, is also meaningful). As we learn from the novel,

Grandma and Josef differed a lot - in terms of height, gender, the way you handle yourself when bowing to say "good morning", the way you smoke when standing for twelve hours in the cold for a pair of camp slippers. Despite these differences, however, Josef became closer to grandma than any of us, than all the walks to the conversations-filled lake, than cuddling to grandma's aproned bosom (Wiśniewska-Grabarczyk 2018: 50).

Porzeczkowy Josef is a kind of a spiritual autobiography that extracts crucial, often deeply hidden, emotions from the subconscious. And even though one should not forget that the novel is a work of literature and not a psychological case study, one cannot avoid reading it as a record of the speaker's covert self-therapy which consists in the granddaughter reclaiming and coming to terms with that about which her grandmother is not able to speak - with the memories that were extremely difficult and have thus become menacing, dangerous and sometimes terrifying:

We didn't talk much about Josef. I couldn't bear to catch grandma lying and, knowing her good heart and the sincere practice of whitewashing even the worst people, I expected many inconsistencies in her stories.

$[\ldots]$

A few times, I had the impression that grandma was trying to tell a coherent story, that she would be willing to share with me every minute she lived through. But at the last moment her tongue refused to obey her and her mouth, instead of telling the story, clenched, leaving an unpleasant grimace on her face. In the end, grandma never went beyond the perfunctory "he's not the same man, Anusia", not caring at all about the fact that it was difficult to recreate a complete picture from a single sentence (Wiśniewska-Grabarczyk 2018: 10-11);

I knew grandma's reluctance to tell compact stories, so I had to - hanging on to this single sentence - do the rest myself. Józefa W. did not like to have memories run free in her house which once belonged to Germans. If she revealed anything from her stay in Bergen-Belsen, it was always on the occasion of some current event, some simple action, and always furtively, quickly, without making it the main topic (Wiśniewska-Grabarczyk 2018: 34). 
The granddaughter is the only person that helps her grandmother 'care' after Josef and who is aware of his presence. ${ }^{3}$ The Nazi commandant 'accompanies' her not only at her grandmother's house, but also on her way to school, in class, and by the lake. Ania tries to defend her grandmother against the intruder, giving him a punch or two. She tries to 'remove' the man, throw him out of the attic and her grandfather's bed; yet, at the same time, paradoxically, she is her grandmother's ally in hiding him. They wait for him together every autumn. The granddaughter sometimes defends her grandmother against the intruder, even against the old woman's wish. In this respect, the scene in which Ania thrusts a knife at the Nazi commandant's chest, seemingly by accident, or the scene when she tries to suffocate him with a pillow are symbolic (Wiśniewska-Grabarczyk 2018: 24-25, 84) - the attempts to murder Josef show the granddaughter's love for her grandmother. The struggle with the traumatic, though not her own, past becomes amplified further in the symbolic scene when Josef tries to drown Ania (Wiśniewska-Grabarczyk 2018: 47-48). The scene in the water, which symbolises the subconscious, indicates a hidden aspect of the struggle. The granddaughter is attacked by a recollection of a painful experience which does not belong to her, but which she decides to bear to save her dear grandmother the pain.

\section{Taste. A Menu Instead of a Record of Harm}

In the world depicted in Porzeczkowy Josef, the act of coping with painful experiences from the past is presented through many descriptions of sensory perceptions, which work on various levels. The novel serves as a covert record of an emotional shift: from pain and a sense of harm to acceptance and love. What plays the main role in compensating for the characters' emotional deficits is taste, which is why food is so important in the novel. The act of writing about food is supposed to replace the act of writing about trauma.

Ania's first encounter with Josef takes place by a currant bush.

I met Josef in June by the currants. He suddenly leaned out, completely unexpectedly, and I immediately broke out in unpleasant sweat. The man came up to the bush and ate a couple of berries, glancing at them, then at me. I felt I was all wet, my shirt was drenched and every bit of it stuck to me - as far from the intruder as possible. The sun was on my left and Josef on the right - I had nowhere to run away, so I started to

3 There is another character who is also worth mentioning. N'kulu, a black domestic servant who aids Ania in 'protecting' her grandmother from Josef, and who after the old lady's death, turns into a doll (no longer needed to protect anyone), uncannily similar to Ania's childhood toy. Thus, she could be seen as the granddaughter's alter ego. This scene makes an intertextual reference to the oneiric symbolism of Bruno Schulz's The Street of Crocodiles (in which a real horse is transformed into a toy horse). 
swallow the white and red fruit faster than ever, as if stripping the whole green bush of these baubles could change something in my situation. Josef certainly sensed the nervousness, because he started reaching for the currants more boldly, taking a step in my direction with every bite (Wiśniewska-Grabarczyk 2018: 6-7).

The act of eating the berries greedily is a way of coping with the tension caused by the encounter. This emotional eating (taking the form of a binge-eating disorder) is a mechanism that protects one from breaking down. The novel includes many examples of using taste to obscure anxious narrations. In the symbolic scene when Josef tries to drown Ania, when fighting the assailant, the girl recalls or rather "can taste in her mouth the tart taste of the white fruit (currants) her grandpa brought in a milk can". In the narrative, the experience of drowning becomes intertwined with an encounter with her grandfather, and thus the line between those events is blurred:

"Look how big they are," he [grandpa] said, spilling a whole handful of currants into his wrinkled palm. "They have the most vitamins and juice, for my granddaughter." Grandpa no longer had to advertise the fruit which, methodically, one by one, vanished in my smiling face. However, it was getting more difficult to eat, as the water, earlier only in my mouth, now broke lower without much trouble and filled my throat. The buzz was getting less annoying, as my ears became used to the muffled, monotonous sound, so I began to appreciate this prolonged bath, this drifting under the surface of Trzcianka lake. Bubbles started popping out of my nose irregularly and out of my control. My chest was working with less and less precision. I was dying there on the beach in Trzcianka, cuddled in a stinking Nazi uniform. I was still a teen and my whole life was wide open ...

"Oh you, oh you," said grandpa, pinching my puffed-out cheek, from which three uneaten baubles came out... I started choking.

The convulsions became so strong, that by some miracle, by a twist of fate, or with a last ditch effort, I managed to escape his grip (Wiśniewska-Grabarczyk 2018: 47-48).

The other major taste in the novel, apart from that of currants, is the sweet taste of hot paczki (Polish doughnuts), associated with the grandmother's recollections of Bergen-Belsen where she fried them. That job, her beauty, and the commandant's sympathy probably saved her life. Pączki were often served in the grandmother's house, yet they were not only a snack - they were a topic which could replace a conversation about camp experiences. Here is an example of such a substitution:

I have never asked what Josef was like in the camp: whether he made good doughnuts, whether he chose sweet stuffing himself or left the matter of filling to the workers; whether he preferred doughnuts with wild rose or plum; what he looked like while beating grandma's increasingly swollen butt. 
"Grandma, are German doughnuts different from ours?" I should have asked, but I missed my chance.

As far as I can remember, our conversations about the German were very disorderly. In hindsight, they should have formed a cohesive whole, but they disintegrated without betraying either the end or the beginning, leaving the middle to be filled (Wiśniewska-Grabarczyk 2018: 10).

The substitution is emphasised at the lexical level by the use of the words "filling" and "filled" in various contexts - one can fill paczki with sweet jam, just as one can fill a conversation with camp stories. Yet, the latter does not happen. The grandmother wants to protect her granddaughter from the harsh truth.

The symbolic scene from chapter 25 when Józefa and Josef's together make paczki dough is very telling in this respect. The granddaughter tries to step in between them, separate them and take over the job. Yet, she is not allowed to participate this special, tense activity which connects the victim and the perpetrator:

I walked in between my grandmother and the German, but he wouldn't let go of the bowl. Grandma didn't let go either. She looked at me, but I had no idea if she wanted me to work the dough or not. We stood there, all three of us, crowded like herrings, stuck sideways to our neighbours. As I stood there unable to move (and I wouldn't move anyway, the proximity of the Nazi was paralyzing - you never knew what to expect), I couldn't see his face, I just felt an unpleasant smell.

"I can work it now," I said ...

Nobody took up my proposal (Wiśniewska-Grabarczyk 2018: 119).

This scene of making the dough shows a symbolic act of pushing the granddaughter away from the unfinished business between Josef and Józefa. She should not bear the burden of the past - the recollections or fears that are not her own.

Several times throughout the novel, allusions to Josef's behaviour are intertwined with discussions of food. A wide variety of dishes are served on the table in the Trzcianka house. Apart from currants and pączki, these include: a pie (a rhubarb pie), sugar-coated biscuits, jello, potatoes, mugs of steaming hot tea, coffee, cucumbers in vinegar, salad with sour cream, herrings, wild mushroom soup, fried bread with sprinkled sugar, sour cherry soup (a cherry tree grew through a window into the attic, where Josef stayed) (Wiśniewska-Grabarczyk 2018: 51). The Nazi commandant's inseparability from the old lady becomes something evident: "Josef entered our bloodstream; we were not surprised by his constant presence in the living room or the kitchen. When making tea, we poured four, not three, glasses" (Wiśniewska-Grabarczyk 2018: 75). The characters are 
anxious about his absence when they travel by train. When it turns out that he is travelling in the next compartment, they experience a mixture of anxiety and a sense that everything is as it should be. At the same time, the appearance of the Nazi commandant in their surroundings amplifies the women's need for eating:

"I'm hungry," I said, unpacking a bun with cheese.

In front of my eyes, I had the commandant stuffed in his uniform, drenched in sweat. $[\ldots]$

"Don't you want a cucumber?"

"Yummy," I said when I took the first bite.

I loved half-sour pickles. Grandma did too, so there were only three left out of eight she took. And the train didn't even reach the first station ... She forced the last one in my hand, knowing she couldn't resist it if it stayed in the plastic bag (Wiśniewska-Grabarczyk 2018: 131).

Another use of the same device in the novel is the substitution of an account of the arrest of Teresa S. and Józefa W. in a roundup in Poznańs market with a detailed description of the food products that one of the women was carrying at that time in her bag. The description obscures the tragic story that is too difficult to be told:

Teresa S. headed for the market and, as she was in a good mood, she skipped over the pavement lightly, allowing the pleats to stroke her twenty-two-year-old knees, as the orange weave of the bag revealed a barley soup, which she intended for Saturday's dinner. At some point, though, the cream-coloured clogs froze, and the whole plan for today's menu scattered all over the Poznań market square. Potatoes got stuck between the worn cobblestones, carrots, leeks and parsleys stuck up high and the barley got stuck to the toes of black German boots. Three ripe apples, meant to go into the compote, also escaped from the bag. Teresa was one of the first ones to be pushed onto the cart. Grandma stood opposite her and thought all the way through about the things that could be made of such beautiful apples (Wiśniewska-Grabarczyk 2018: 67-68).

The descriptions of food have an additional function amplified by the play on the surname of Józefa W. Teresa S. had an appetite for a sour cherry pie which was the actual reason why she left home and why she was arrested: instead of getting a bite of a cherry pie, she was taken away to the camp with Józefa Wiśniewska (the stem of the surname - "wiśnia” - means a 'sour cherry'). On her way out of the camp, Józefa was offered a sour cherry pie on the tram: "It was hen, on the tram in Poznań, that grandma regained her human attitude to food, this balance between the joy of taste and the need to keep the body alive, between satisfaction and sustenance" (Wiśniewska-Grabarczyk 2018: 133). 
The novel is filled with similar literary devices. After the grandmother's death, the granddaughter says: "I'm all the consistency of pudding, just like grandma" (Wiśniewska-Grabarczyk 2018: 75), referring to the old lady's flaccid dead body, at the same time expressing her own way of mourning. Her recollections of the funeral are mainly the recollections of "goblets of pink-green-white cassata ice cream" (Wiśniewska-Grabarczyk 2018: 81) consumed at Trzcianka’s Szklanka restaurant and of the funeral banquet where, as she recalls, "[she] ate eight eggs, and [her] father - all the chicken aspic" (Wiśniewska-Grabarczyk 2018: 81). The town's topography is also described mainly through the prism of its restaurants ("Zielona Buda", "Biały Róg", "Herbowa", "Szklanka"). Even the description of the strike in Lubuskie Shipyards, in which the protagonist's father participated and which was completely unrelated to the war, includes a separate, half-pagelong paragraph devoted to the presentation of the food products delivered to the striking crew by their families.

\section{Smell. "The nose takes it all"}

The descriptions of tastes are often accompanied by those of olfactory perceptions. The smell of food usually carries positive connotations ("a long whistle came out of the kitchen, and finally the smells of dinner boldly entered the room" [Wiśniewska-Grabarczyk 2018: 53]). Its intensity amplifies other sensory perceptions. The scent of food is pleasant, as sandwiches in students' bags "spread the smell of tomato, ham, cucumber, cheese or egg" (Wiśniewska-Grabarczyk 2018: 40). However, in the novel smells which are easy on the nose are often mixed with the descriptions of stench, stink, and unpleasant olfactory experiences. The fragment about the blending of smells in Bergen-Belsen seems crucial in this respect:

The smell of doughnuts rarely reached the rest of the camp, as it was difficult for it to break through the dominant stench. Sometimes, the commandant would look over the kitchen, especially when Józefa W.'s was already in the barrack. One sunny Sunday, grandma spent all morning in the fumes of lard ... As the pastries she made were not only delicious but also wonderfully pretty, she was put before the commandant. Józefa W. stared at the ground. Her tired legs had trouble carrying her frail body, in which the commandant saw something familiar. It was not only because the aesthetic value of her doughnuts that her grandma returned several more times to the ommandant's office, where there was praise for the girl with a beautiful nose, proper knees, striking a balance between a doughnut and a turnip (Wiśniewska-Grabarczyk 2018: 87-88).

This platitudinous account carries a great tragedy of the young pretty girl who lived at the mercy of the Nazis. The tragic character of her story is not depicted 
directly - it only emerges from the smell of pączki and the odour of frying lard mixed with the stench of the camp. That stench was a common experience in Bergen-Belsen. As Nikolaus Wachsmann recollects,

Even before new prisoners glimpsed the horror that awaited them in Bergen-Belsen, they could smell it. A stench of decay and death - sickeningly familiar to prisoners from camps like Auschwitz - enveloped the compounds during the final weeks. [...] Thousands of inmates soiled themselves, and the whole camp, [...] came to resemble one huge latrine (Wachsmann 2015: 566-567).

Ania's nose "took it all". The protagonist smells the "stinking Nazi uniform" and the stench of his urine. As the narrator explains, "Urine is urine, you can't win with urine" (Wiśniewska-Grabarczyk 2018: 48, 8).

In this context, the author of the novel devotes much space to descriptions of physiology, often in relation to eating:

There was an unpleasant smell of fresh urine from the toilet. The seat was marked with yellow drops scattered in an irregular pattern. I thought of a sandwich with cheese and fresh cucumber. If only I could eat a sandwich instead of smoking. Bite after bite, dismemberment, chewing, swallowing. Initiation cheese instead of suffocating smoke (Wiśniewska-Grabarczyk 2018: 39).

The numerous descriptions associated with olfactory perceptions that can be found in the novel may, similarly to taste perceptions, replace a direct verbal account: it is easier to experience tastes and smells than to listen to traumatic stories or share them with others. Only sometimes, emotions reach a tipping point, causing expulsion ("My head hurt more and more. The milk skin and the smell of vinegar on the aspic came up to my throat - I threw up exactly when the bell rang" [Wiśniewska-Grabarczyk 2018: 82]).

\section{Touch. Between Warm and Cold}

The sense of touch is much less present in the novel; yet it carries a similarly strong emotional load. Severe cold and stench were part of the everyday experience of Bergen-Belsen internees. As Wachsmann states, "At night, inmates faced more agony, with cold winds sweeping through broken roofs, windows, and doors. The barracks were often bare - no lights, straw sacks, covers, stoves, chairs" (Wachsmann 2015: 567). After returning from the camp, Józefa W. first experienced the "presence" of the commandant when she tried to no avail to warm her cold-ridden body in a bathtub. In the novel the sensation of coldness passes onto the granddaughter. The narrative blurs the line between the descrip- 
tion of the sensations of coldness experienced by women in the camp and the description of Ania's cold feet, which become linked:

Józia and Teresa S. were [...] more sensible and hid their hands, knees, noses and foreheads under the blanket, cuddling up to one another. Owing to that, it was ultimately not the night frost that dealt the final blow to one of them. The chill of the barrack went right through me, goose bumps appeared on my hands and back.

"Oops." The comb fell out of her numb fingers. N'kulu and grandma sat in front of the TV, without complaining about the temperature (Wiśniewska-Grabarczyk 2018: 34-35).

Years later it is the granddaughter that seems to feel cold rather than her grandmother, as if the former has substituted the latter. This is, for instance, conspicuous in the intense coldness of Ania's feet.

This sense of identification between the two characters is visible on several levels. Wiśniewska-Grabarczyk's novel makes a number of associations which show how people's fortunes are intertwined with each other and emphasize their interdependence. For example, Teresa S. lost her clogs, which in the camp was basically a death sentence:

Grandma and all of her barrack companions already stood at the roll call, while Teresa S. kept looking for her lost possession, which had to be found, as it had been drizzling all morning. It was clear that there was no chance of survival without shoes in such foul weather. Should the call last a couple of hours, the feet let all the moisture travel up, and then all it takes is a couple of minutes till the body finally gives in (Wiśniewska-Grabarczyk 2018: 114).

Józefa W. was unjustly accused of the theft and beaten badly by the commandant. Thus, Teresa S.'s cold feet and her lost shoes entered the world of the Wiśniewskis and the world of the novel.

A hot-water bottle becomes a major item of everyday use. The granddaughter's feet are often cold ("I pulled my feet up and gave them a warming massage" [Wiśniewska-Grabarczyk 2018: 25]; "I felt dizzy, so I moved to the chair and rubbed my feet, which were still cold" [Wiśniewska-Grabarczyk 2018: 24]; "If the temperature dropped by a dozen or so degrees, I could squeeze my cold feet between the tangle of my grandmother's legs and a metal heater the colour of a cherry pudding" [Wiśniewska-Grabarczyk 2018: 26]; "I cuddled up with grandma, moving the hot-water bag to the middle so we could both warm our feet" [Wiśniewska-Grabarczyk 2018: 36]; "after a long time, the heat from grandma and the bag spilled over my numb feet" [Wiśniewska-Grabarczyk 2018: 37]). Those who are able to unknowingly break the overwhelming cold are 
Paweł and Ania's child. As the narrator explains, "I remember the heat that spilled all over my back when, pushed against the German bricks. I said goodbye to Paweł. The same heat would have reached me in a dozen or so years' time, when we were drinking lemonade with our son, leaning against Szklanka" (Wiśniewska-Grabarczyk 2018: 74). The love between the family members constitutes a kind of an 'antidote' to Josef.

Yet, this is not the end of parallels and associations. The commandant's shoes are yet another shared element. Josef's tattered boots are replaced with the shoes... of the dead grandfather; the Nazi commandant receives them from the grandmother who is moved by compassion. Perversely, at least in symbolic terms, this gesture of good will eventually helps the characters experience the warmth that they so much desire. As we learn from the novel,

Eventually, the Nazi's shoes ended up in the grandpa's stove. On Thursday morning I went with my grandma to make a fire. The worn jackboots kept burning till Friday, heating the house all day and all night (Wiśniewska-Grabarczyk 2018: 56).

The Nazi commandant's touch, which usually transforms into a struggle and a scuffle, is typical of the scenes in which the protagonist tries to remove the intruder or defend herself against his attacks. One significant example (apart from the above-mentioned drowning scene) is the fight scene from chapter 14. It depicts an attempt to suffocate the Nazi, which eventually ends in the intruder's victory. It is preceded with a series of persistent dreams in which Josef lies in bed between the grandmother and the granddaughter:

Josef got into bed, climbed in, invaded, barged in, and just lied there in the sheets. I entered the room completely unprepared for this. I stood there, in my fresh pyjamas, in green slippers, before a man in a uniform chuckling at the TV screen. I tip-toed to the chair and started stirring the sugar in the full sugar bowl. Luckily, time was gracious, and the evening immediately turned into night...

"I don't remember getting to bed," I thought to myself when I realised that I was lying down.

I raised my head and saw my grandma facing the wall. I lost my safe balance and caught the German lying between us. Only then did I realise I was embracing the war criminal. The body of the intruder was sticky and slippery, close to what death would do in a few years' time with the body of my beloved grandma... Once again, I lifted myself up, this time propped on my elbow, and looked at my grandmother covered in a rough nightgown. My eyes were playing tricks on me as Josef's mug was almost indistinguishable from the greyness of grandma's pyjamas. The German was lying on his back, but his muzzle was facing the wall. I had never been so close to the creature and I was not sure whether he was always so worn or whether he had lost all the qualities of a human over time (Wiśniewska-Grabarczyk 2018: 82-83). 
The attempt to choke the Nazi commandant with a pillow is an attempt to remove him from the characters' lives. Considering the frequent references that the narrative makes to Schulz's oneiric prose, one could view this act as a kind of "oneiric wrangle" aimed at the elimination of the traumatizing element. As Wojciech Owczarski writes, referring to the author of The Street of Crocodiles,

That is because the purpose of a dream is to digest and excrete, to consistently dispose of all memories, experiences, visions, emotions, reactions, and behaviours which might interfere with the image of the "self". A dreamer excretes any remainders that do not fit all that they wish to become (Owczarski 2014: 118).

In the world presented in Porzeczkowy Josef sensory perceptions and their symbolic meanings are mixed with one another: the act of eliminating trauma may be presented as a struggle or as digestion and excretion. Actually, it is often impossible to separate various sensory perceptions which become amplified in particularly significant moments. One such moment is the last "meeting" between the granddaughter and the grandmother, bound together in symbiotic trauma, ${ }^{4}$ in the funeral scene. The stench of cold wreaths in an air-conditioned funeral home clashes with the summer heat. The granddaughter with goose bumps on her arms and the "sweating" body of the deceased grandmother form a symbiosis:

Beloved forehead, beloved temples, beloved cheeks - everything worked like a living thing on this July morning, responding with sweat to the attacks of nature. And she was all as shining as Madonna, some kind of saint from Trzcianka. And this sainthood was probably also due to the fact that my grandma, dressed in heavy black shoes on winter tights and a pencil skirt, not only black, but also with double lining, sweated from her legs, her feet, her toes, the same ones that cuddled with my feet on a hot-water bag every winter. I felt sorry for grandma and for myself, and her sweaty legs, so I pressed my forehead against hers, nose to nose, myself to this brightness. And then I felt that it was not the brightness that was the first feature of the corpse, but the stickiness (Wiśniewska-Grabarczyk 2018: 76-77).

\section{Sight. A View of Josef}

The sense of sight plays a similar role to that of taste, smell, and touch. First of all, it becomes a tool used for monitoring the presence of Josef who keeps coming into the grandmother's and the granddaughter's sight:

4 I have borrowed the term "symbiotic trauma" from Franz Ruppert, a German professor of psychology and a therapist, who works on the identity-focussed theory and therapy of psychotrauma (Ruppert 2012). 
when properly positioned, you had a pretty good view from the kitchen of a piece of the cherry tree coming in through the attic window, a piece of an attic wall and a large piece of Josef. Because of this, I prepared every meal under the eye of the German, whose presence became a necessary ingredient of my cooking for a long time (Wiśniewska-Grabarczyk 2018: 51).

The perception of Josef changes in time. When Ania sees him trapped in currant bushes with a rope on his neck cutting into his skin (Josef Kramer was hung in 1945 for his war crimes) and with a urine stain between his legs, he does not evoke fear in her but rather disgust ("I was taken aback by his smell" [Wiśniewska-Grabarczyk 2018: 8]). Her reaction is similar when the Nazi commandant appears as a helpless figure in a tattered uniform at the mercy of the hosts. However, the situation is much different after Josef starts regaining his self-confidence, when he starts throwing his weight around at the grandparents' house, as well as in the scenes of killing Ania’s beloved dogs: Pikuś and Krzak. It seems that the imaginary figure starts regaining the strength that he used to have when he was in charge of the camp. This is most conspicuous in the description of his appearance: the neater it gets, the crueller he seems and the more fear he evokes:

Passing by the Nazi, I had the impression that there was something new in his appearance. At first glance he just seemed taller than usual, but the next day there was also something else - Josef became brighter but with regular down-to-earth explainable light which became stronger when contrasted with his earlier appearance. There was no longer a green patina on his buttons, the furrows on his cleaned paws were twice as deep, the scrubbed muzzle finally revealed his wild eyes, low forehead and a large scar on the left cheek. Fortunately, when I opened the gate, the beast kept a little bit of fear and took two steps back. When I found myself on the other side, I felt that I was all sweaty, that my legs were shaking, and I was short of breath (Wiśniewska-Grabarczyk 2018: 54-55).

The novel's world is filled with the colours of nature related to consecutive seasons. The colourful (though sometimes shrouded in darkness) world tries to obscure tragic recollections. Just as in the case of food, the description of the colourful clothes of the newly arrived women internees aims to replace the too-painful-to-tell story of these women:

The knee breaking the pleats of a pea-coloured skirt, the knee covered with viscose that came from the vicinity of Częstochowa, the knee covered with orange tights illuminated the camp greyness only for the first few days, after which they lost their colour and freshness. The most anticipated sight was that of knees accompanied by the colour green, which the internees missed the most (Wiśniewska-Grabarczyk 2018: 116). 
The scene of the camp roll call is shown in a similar manner. The commandant executing internees is depicted with the use of a synecdoche - it is not the perpetrator that is the master of life and death but rather his coat:

The body fell silently when the trench coat stopped in front of Teresa S. A terrible, black trench coat stuffed in the shoulders like a boxer. It descended lightly on the back, and from the waist down it moved with the wind, rising to the hips every now and then ... The trench coat gave an order to pick every second pair, so Teresa S. won another couple of months of life (grandma lived to see me graduate) (Wiśniewska-Grabarczyk 2018: 86).

\section{Two Deaths}

Anna Wiśniewska-Grabarczyk's novel begins and ends with the motif of death. The description of the death of the grandmother binds the story. The fragment which concludes the novel also stresses the significance of sensory perceptions (taste, the feelings of cold and warmth) which play an important role in the whole narrative:

My grandma died twice. First time in the heart of Bergen-Belsen, in its oldest part. Delicious doughnuts were served there, poked with a stick in hot lard. In the winter, frost twisted the toes, while lard burned the fingers. A doughnut and a couple of hours in a heated barrack of the commandant were the reward for these inconveniences. The second time my grandmother died was in the heart of Trzcianka, on the stairs (Wiśniewska-Grabarczyk 2018: 143).

Porzeczkowy Josefis a book about two kinds of death: a spiritual one, which the protagonist suffered due to severe camp trauma, and a physical one, which took place several decades later. The former becomes the main theme of the story, a story mainly about the love of a granddaughter for her grandmother, which "usurps" the burden of the story of the loved one. This specific form of inheritance is conspicuous not only in the events described in narrative, but also in the distorted chronology of the novel and the fluid structure of space which does not aim at a realistic representation of the world but seeks to convey the narrator's emotions (on the day the grandmother died "not only did time fell down the well, but space stood up against yesterday's city map" [Wiśniewska-Grabarczyk 2018: 112]).

The fragmented construction of the novel also plays a major role in this context - the story consists of loosely related fragments styled to resemble recollections (33 mini-chapters the longest of which is a few pages long while the shortest includes only 3 concise sentences). They are not organized in terms of time or space. The world of the living co-exists alongside the world of the dead. 
The dates mentioned in the novel are misleading, even though sometimes those "mistakes" suggest how to decipher the message of the text (the grandmother dies on 25 July 1992 and three years later she defends her granddaughter against Josef's attack; also in 1995 Ania meets her deceased friend; this indicates that the protagonist has in a sense entered the world of the dead, further amalgamating the readers' conviction about the protagonist's symbiotic entanglement). These organizational strategies help make the autobiographical story about Trzcianka and its inhabitants a well-thought-out spiritual autobiography saturated with symbolic meanings and multi-layered semantics.

\section{BIBLIOGRAPHY}

Artwińska Anna. 2016. Transfer międzypokoleniowy, epigenetyka i 'więzy krwi'. O "Matej Zagtadzie" Anny Janko i "Granicy zapomnienia” Siergieja Lebiediewa. "Teksty Drugie”, no. 1. ISSN: 0867-0633. Pp. 13-29.

Bergen-Belsen. 2020. In: Holocaust Encyclopedia [online]. https://encyclopedia.ushmm. org/content/en/article/bergen-belsen [21.04.2020].

Bilczewski Tomasz. 2013. Trauma, translacja, transmisja w perspektywie postpamięci. In: Od pamięci biodziedzicznej do postpamięci. Ed. Teresa Szostek, Roma Sendyka, Ryszard Nycz. Warszawa: Wydawnictwo IBL PAN. ISBN: 978-83-61552-80-2. Pp. 40-62.

Bojarska Katarzyna. 2013. Wydarzenia po Wydarzeniu. Biatoszewski-Richter-Spiegelman. Warszawa: Wydawnictwo IBL PAN. ISBN: 978-83-6155-259-8.

Chen Alon. 2019. Epigenetyka: jak dziedziczymy traumy. Wywiad z kierownikiem i pracownikiem naukowym Instytutu Psychiatrii im. Maxa Plancka. "DW News" [online] 29.09.2019. https://www.dw.com/pl/epigenetyka-jak-dziedziczymy-traumywywiad/a-50625755 [10.03.2020].

Czyż Piotr A. 2013. Wspomnienia Henryki Tajchert z Wtodawy - więźniarki Zamku Lubelskiego, Ravensbrück i Bergen-Belsen. "Radzyński Rocznik Humanistyczny”, no. 11. ISSN: 1643-4374. Pp. 71-84.

Hirsch Marianne. 2012. Mourning and Postmemory. In: Family Frames: Photography Narrative and Postmemory. Cambridge, Massachusetts-London, England: Harvard University Press. ISBN: 978-14-7000-748-5.

Jośko-Ochojska Jadwiga. 2018. Trauma dziedziczona. Interview by Monika Stelmach. "Psychiatria po Dyplomie" [online], no. 3. https://podyplomie.pl/psychiatria 130766,trauma-dziedziczona [10.03.2020].

Owczarski Wojciech. 2014. Sennik polski. Literatura, wyobraźnia i pamięć. Gdańsk: słowo/obraz terytoria. ISBN: 978-83-7453-271-6. 
Ruppert Franz. 2012. Symbioza i autonomia. Trauma symbiotyczna i mitość bez uwiktań. Trans. Zenon Mazurczak. Warszawa: Wydawnictwo Czarna Owca. ISBN: 978-83-7554-319-3.

Ślady II wojny światowej i Zagtady w najnowszej literaturze polskiej. 2016. Ed. Barbara Sienkiewicz, Sylwia Karolak. Poznań: Wydawnictwo Nauka i Innowacje. ISBN: 978-83-6486-439-1.

Teoria wiedzy o przesztości na tle wspótczesnej humanistyki. Antologia. 2010. Ed. Ewa Domańska. Poznań: Wydawnictwo Poznańskie. ISBN: 978-83-7177-701-1.

Wachsmann Nikolaus. 2015. KL: A History of the Nazi Concentration Camps. New York: Farrar, Straus and Giroux. ISBN: 978-03-7411-825-9.

Wiśniewska-Grabarczyk Anna. 2018. Porzeczkowy Josef. Warszawa: Anagram. ISBN: 978-83-6555-428-4.

Wojna i postpamięć. 2011. Ed. Zbigniew Majchrowski, Wojciech Owczarski. Gdańsk: Wydawnictwo Uniwersytetu Gdańskiego. ISBN: 978-83-7326-739-8.

\section{Marzena Woźniak-Eabieniec}

\section{APPROACHING EMOTIONAL DEFICITS THROUGH THE LENS OF EPIGENETICS. THE SENSORY SUBLIMATION OF TRAUMA IN ANNA WIŚNIEWSKA-GRABARCZYK'S PORZECZKOWY JOSEF}

(abstract)

The article examines Anna Wiśniewska-Grabarczyk's Porzeczkowy Josef (Currant Josef), which was nominated for the 2019 Witold Gombrowicz Literary Award, from the epigenetic perspective. The novel tells a story of coping with the difficult memories of a concentration camp. Those experiences and the anxiety that they produce were 'inherited' by the granddaughter from her grandmother. In the suppressed memories, love merges with hatred and the victim's attachment to the perpetrator - with shame. As the article argues, what plays an important role in coping with this trauma are richly described sensory impressions (scents, flavours, tactile impressions).

SŁOWA KLUCZOWE

Anna Wiśniewska-Grabarczyk; literatura a pamięć; postpamięć; epigenetyka; Shoah 